\title{
Effects of Chlorine, Iodine, and Quaternary Ammonium Compound Disinfectants on Several Exotic Disease Viruses
}

\author{
Junsuke SHIRAI, Toru KANNO, Yoshinori TSUCHIYA, Satoru MITSUBAYASHI') and Reiji SEKI ${ }^{1)}$ \\ Department of Exotic Diseases, National Institute of Animal Health, 6-20-1, Josuihoncho, Kodaira, Tokyo 187-0022 and ${ }^{1)}$ Tamura \\ Pharmaceutical Co., Ltd., 1-4 Kanda Jinbocho, Chiyoda-ku, Tokyo 101-0051, Japan
}

(Received 23 July 1999/Accepted 27 September 1999)

ABSTRACT. The effects of three representative disinfectants, chlorine (sodium hypochlorite), iodine (potassium tetraglicine triiodide), and
quaternary ammonium compound (didecyldimethylammonium chloride), on several exotic disease viruses were examined. The viruses
used were four enveloped viruses (vesicular stomatitis virus, African swine fever virus, equine viral arteritis virus, and porcine reproductive
and respiratory syndrome virus) and two non-enveloped viruses (swine vesicular disease virus (SVDV) and African horse sickness virus
(AHSV)). Chlorine was effective against all viruses except SVDV at concentrations of $0.03 \%$ to $0.0075 \%$, and a dose response was
observed. Iodine was very effective against all viruses at concentrations of $0.015 \%$ to $0.0075 \%$, but a dose response was not observed.
Quaternary ammonium compound was very effective in low concentration of $0.003 \%$ against four enveloped viruses and AHSV, but it was
only effective against SVDV with $0.05 \% \mathrm{NaOH.} \mathrm{Electron} \mathrm{microscopic} \mathrm{observation} \mathrm{revealed} \mathrm{the} \mathrm{probable} \mathrm{mechanism} \mathrm{of} \mathrm{each} \mathrm{disinfectant.}$
Chlorine caused complete degeneration of the viral particles and also destroyed the nucleic acid of the viruses. Iodine destroyed mainly
the inner components including nucleic acid of the viruses. Quaternary ammonium compound induced detachment of the envelope of the
enveloped viruses and formation of micelle in non-enveloped viruses. According to these results, chlorine and iodine disinfectants were
quite effective against most of the viruses used at adequately high concentration. The effective concentration of quaternary ammonium
compound was the lowest among the disinfectants examined.-KEY worDs: disinfection, electron microscopy, exotic disease virus.

Preventing the entry and spread of infectious disease agents is a critical step in controlling infectious diseases, and the effective use of disinfectants is a vital and necessary measure for the control of infectious routes. Historically, there are many instances when disinfectants have been used successfully in the control and prevention of both human and animal infectious diseases $[2,8]$. The notifiable animal infectious diseases, named in the Office International des Epizooties (OIE) list A diseases, were mostly viral diseases [19]. However, effects of disinfection against these exotic viral agents have been not investigated in Japan. There is little information for the routine disinfection for the protection against these pathogens. Therefore we studied the effects of representative disinfectants on exotic disease viruses.

The viruses used in this study and its selected reasons were as follows. Swine vesicular disease virus (SVDV) belongs to a family picornaviruses similar to foot-and-mouth disease virus (FMDV) and causes a disease similar to FMD. But SVDV has stronger resistance to chemicals and disinfectants than FMDV [1,9]. African horse sickness virus (AHSV) belongs to the orbiviruses and it causes severe or even fatal disease in horses. Vesicular stomatitis virus (VSV) belongs to rhabdoviruses and it causes a disease similar to FMD [4]. African swine fever virus (ASFV) is a pox-like virus and it causes a disease similar to classical swine fever [20]. Equine viral arteritis virus (EVAV) and porcine reproductive and respiratory syndrome virus (PRRSV) belong to the arteriviruses. EVAV causes reproductive failure in horses and it is a most threatening disease for horse racing in Japan [15]. PRRSV is not an exotic disease virus in Japan now [17], but it is a new disease virus; therefore, a disinfection against this virus has not been tested well.

\section{MATERIALS AND METHODS}

Viruses and cell culture: The J1 strain of SVDV [23], the New Jersey strain of VSV [4], the Lisbon strain of ASFV [20], the type 4 vaccine strain of AHSV [16], the modified Bucyrus strain of EVAV [15], and the EDRD strain of PRRSV [17] were used in this study. SVDV and VSV were propagated in IBRS-2 cells [11]. ASFV and AHSV were propagated in Vero cells [16]. EVAV and PRRSV were prepared in Marc-145 cells [17]. The viral samples of SVDV, VSV, AHSV were prepared in cells cultured with the serum free medium, but those of ASFV, EVAV, and PRRSV were prepared in cells cultured with the medium containing $2 \%$ bovine serum.

Virus titration: The virus titers before and after treatment with disinfectants were titrated in each of culture cells. The titration of SVDV and VSV was carried out by plaque formation method as previously described [11] and the titers were expressed as plaque-forming unit (PFU) per $0.1 \mathrm{~m} l$. The titers were expressed as $50 \%$ tissue culture infectious dose $\left(\mathrm{TCID}_{50}\right)$ per $0.1 \mathrm{~m} l$ in ASFV, AHSV, EVAV and PRRSV.

Disinfectants: A commercial chlorine disinfectants containing 6\% sodium hypochlorite (SHC) (Purelox, 6\% (w/v) Ohyalax Co., Ltd.) was used for chlorine disinfectant. 
A commercial iodine compound disinfectant containing 3\% potassium tetraglicine triiodide (PTT) (Poliup-3, 3\% (w/w) Kyowa Hakko Kogyo Co., Ltd.) was used for iodine disinfectant. Commercial quaternary ammonium compound containing $10 \%$ didecyldimethylammonium chloride (DDAC) (Cleakil-100, 10\% (w/v) Tamura pharmaceutical Co., Ltd.) was used for the quaternary ammonium compound.

Assay procedures for virucidal activity: The chlorine disinfectant (6\% SHC) diluted in 1/100, 1/200, 1/400, 1/ $800,1 / 1,600$, and $1 / 3,200$ was used. The iodine disinfectant (3\% PTT) diluted in $1 / 100,1 / 200,1 / 400,1 / 800,1 / 1,600$, and 1/3,200 was used. The quaternary ammonium compound (10\% DDAC) diluted in 1/400, 1/800, 1/1,600, $1 / 3,200,1 / 6,400$, and 1/12,800 was used. Each virus sample was directly used and mixed with equal volume of each diluted disinfectant and the mixtures were incubated at room temperature for $30 \mathrm{~min}$. Following incubation, the specimens were immediately diluted in tissue culture medium containing $5 \%$ calf serum and titrated.

Each virus sample except for ASFV was mixed with an equal volume of each adequately diluted disinfectant and incubated at room temperature for 1, 5, 10, 30, and $60 \mathrm{~min}$. Then the specimens were immediately diluted in tissue culture medium containing 5\% calf serum and titrated. Specimens diluted in distilled water and incubated for 60 min were used as a control.

Electron microscopy: SVDV, VSV, AHSV, and PRRSV were propagated in roller bottle and purified for examination by electron microscopy. The purified viruses were mixed with an equal volume of distilled water, $0.06 \%$ of $\mathrm{SHC}$ in chlorine disinfectant $(0.12 \%$ of SHC for SVDV), $0.03 \%$ of PTT in iodine disinfectant, or $0.025 \%$ of DDAC in quaternary ammonium compound and allowed to stand for $30 \mathrm{~min}$ at room temperature. One drop of each sample was mounted on a 400-mesh carbon-coated grid, and negatively stained with $2 \%$ phosphotungstic acid, $\mathrm{pH} 7.05$, for $1 \mathrm{~min}$. The samples were examined in a JEM-1200 EX electron microscope (JEOL Ltd., Tokyo, Japan).

\section{RESULTS}

Virucidal activity of disinfectant: The effects of the concentration of each disinfectant are summarized in Figs. 1,2 , and 3 . The effects of the chlorine disinfectant were observed at the final concentrations from $1 / 200$ to $1 / 800$. The effective concentration of this disinfectant were $0.03 \%$ to $0.0075 \%$ for SHC, calculated from the original concentration of SHC in the starting material. But a slight effect of chlorine against SVDV was observed at high concentration. The effects of chlorine varied depending on the viral species. A dose response was observed for the chlorine disinfectant, so a small amount of virus was inactivated by a lower concentration of disinfectant (Fig. 1). The effects of the iodine disinfectant also were observed at the final concentrations from $1 / 200$ to $1 / 400$. The effective concentrations of the iodine disinfectant were $0.015 \%$ to
$0.0075 \%$ for PTT, calculated from the original concentration of PTT in the starting material. Iodine was effective against SVDV at a concentration of $1 / 200$. The effects of iodine were variable depending on the viral species. However, a dose response was not observed for the iodine disinfectant (Fig. 2). The effects of quaternary ammonium compound were observed at the concentration of 1/3,200 against all enveloped viruses. The effects of quaternary ammonium compound against AHSV was observed at the concentration of $1 / 800$. But no effect was observed against SVDV. The effective concentration of this disinfectant was $0.003 \%$ of DDAC calculated from the original concentration of DDAC in the starting material. The effective concentration of DDAC against AHSV was $0.0125 \%$. A dose response was observed for quaternary ammonium compound and small amounts of the viruses were killed by a concentration of 1/ 12,800 (Fig. 3). No cytotoxicity was observed when the disinfectants were diluted more than 1:200.

The effects of time of exposure to each disinfectant against all of the viruses except for SVDV were within 10 min in the adequate concentration. However, the effect of time for disinfection showed clearly the sensitivity of each virus to each disinfectant; for example, EVAV and PRRSV are more resistant to chlorine disinfectant and VSV is more resistant to each disinfectant than other viruses. The effect of iodine disinfectant against SVDV was within $5 \mathrm{~min}$, but those of other disinfectants were $60 \mathrm{~min}$. This showed that SVDV was the most resistant virus to disinfection (Table 1).

Electron microscopy: Electron micrographs of virus particles affected by the compounds are shown in Figs. 4 and 5. Figure 4 shows the effects of each disinfectant against AHSV. Round viral particles $50 \mathrm{~nm}$ in diameter were observed in control material (Fig. 4-a). Non-structural substances shaped like micelles produced by the effects of quaternary ammonium compound were observed (Fig. 4-b). Definitive particles that lost nucleoprotein by exposure to chlorine disinfectant were observed (Fig. 4-c). Definitive viral particle aggregation was observed in the iodine disinfectant material (Fig. 4-d). Figure 5 shows the effects of each disinfectant against VSV. Bullet shape particles about $120 \mathrm{~nm}$ in diameter were observed (Fig. 5-a). The virus envelopes were completely removed by quaternary ammonium compound, and the inner structure (nucleoprotein) was clearly observed (Fig. 5-b). The virus particles were completely degenerated by chlorine and the shape of the viral particle changed to round (Fig. 5-c). Definitive particles whose inner structure was destroyed by iodine disinfectant were observed, but their outer structure remained (Fig. 5-d). The effects of each disinfectant on SVDV and PRRSV were also observed in the electron microscope. In SVDV specimens, the virus particles were gathered by quaternary ammonium compound, but each viral particle retained its intact form. Completely destroyed particles or definitive viral particles were observed in the chlorine and iodine disinfectant material. In PRRSV specimens, the viral particles were completely destroyed by 

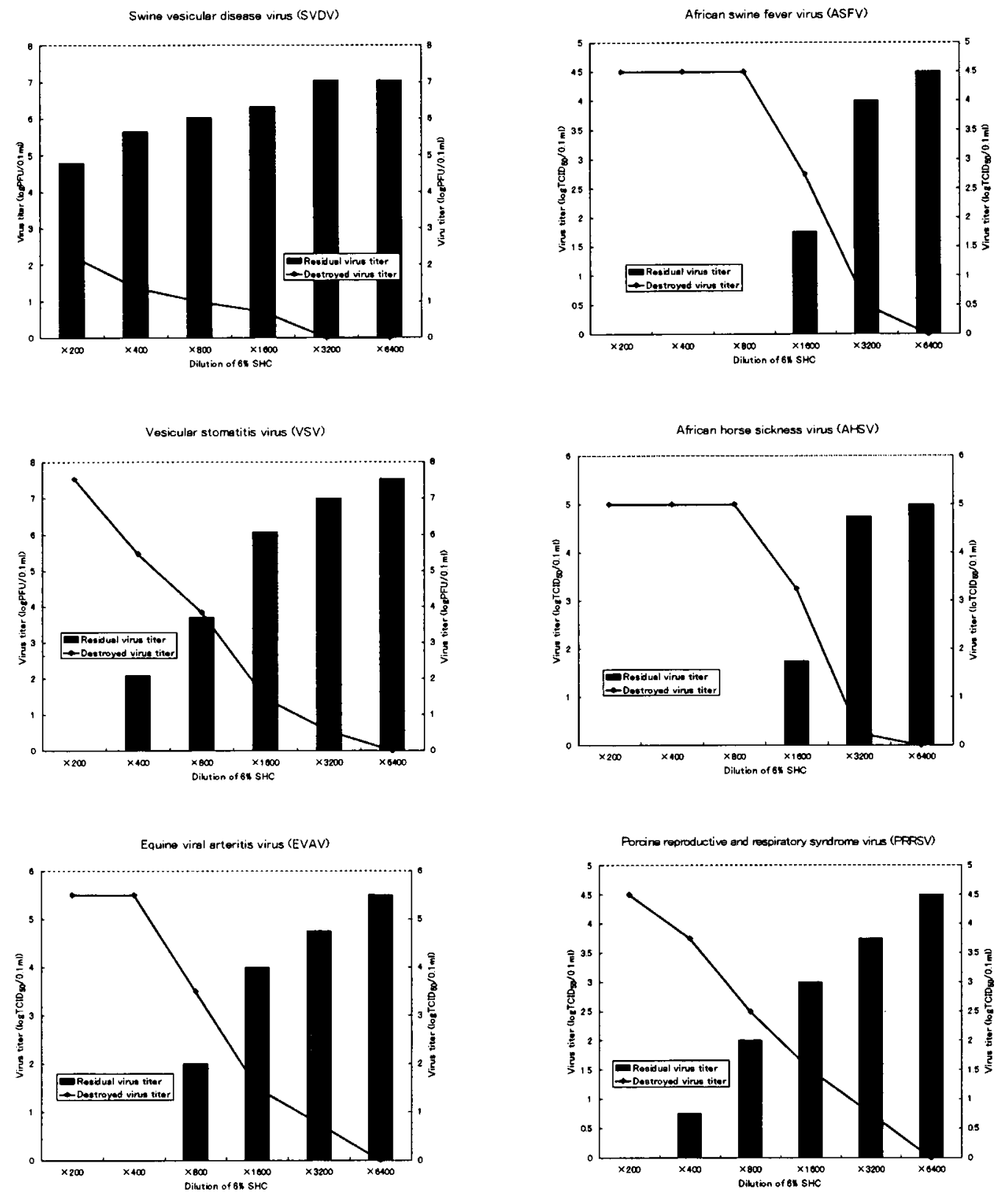

Fig. 1. The effects of chlorine disinfectant against several exotic disease viruses. Lines show the titers of the inactivated virus. Bars show the remaining virus titers. SVDV and AHSV are non-enveloped viruses. VSV, ASFV, EVAV, and PRRSV are enveloped viruses. SHC is the initial letters of sodium hypochlorite.

quaternary ammonium compound; however the outer structure remained. The viral particles were destroyed but a few intact particles were observed in the chlorine disinfectant material. The definitive particles were observed in the iodine disinfectant material.

\section{DISCUSSION}

The outbreak of FMD in Taiwan [6] is a big threat for Japanese animal industries because of its enormous damage.
The first eradication strategy against the outbreak of FMD started from effective disinfection, because FMD spread very rapidly. Almost all the important animal diseases called exotic diseases of Japan are caused by viruses [19]. Therefore, good disinfection against viruses is important for disease control. There are eight main kinds of disinfectants now in use, chlorine, peracetic acid, and iodine compounds are effective disinfectants against viruses [10]. But peracetic acid is too expensive to be used in routine disinfection. Therefore, chlorine and iodine compounds were used for 
SVDV

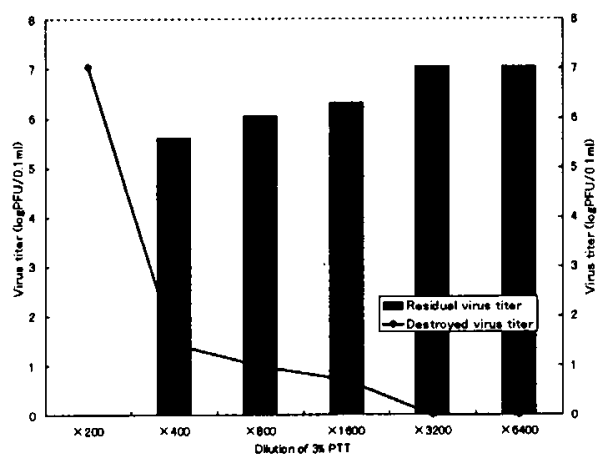

VSV

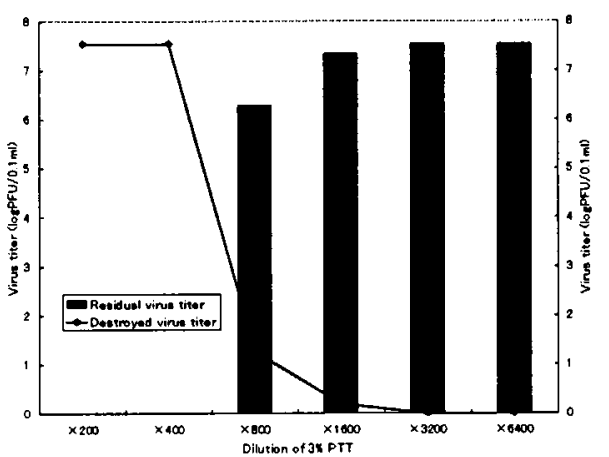

EVAV

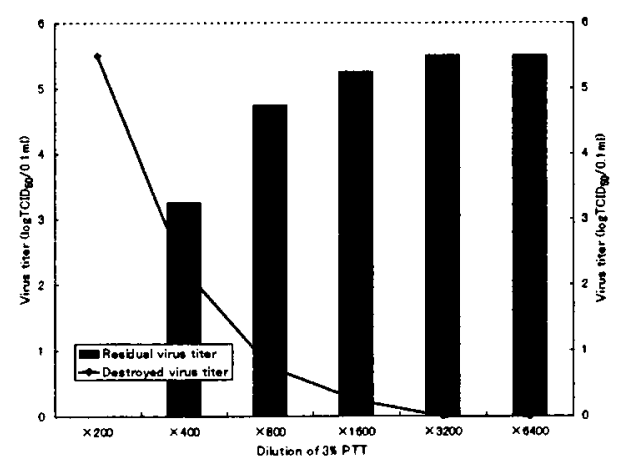

ASFV

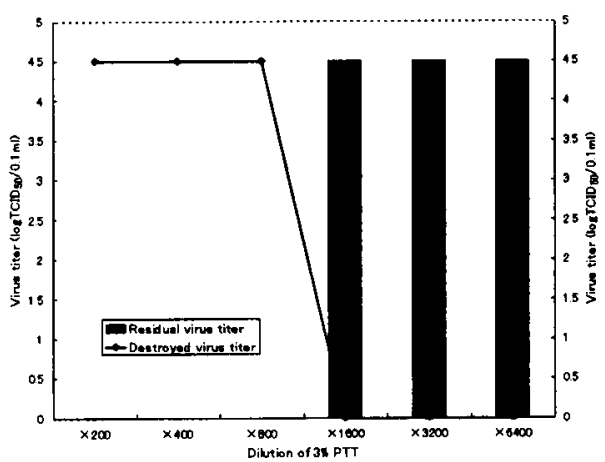

AHSV

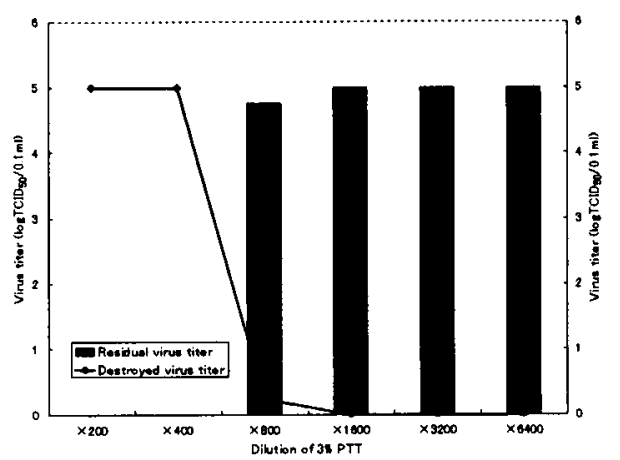

PRRS $V$

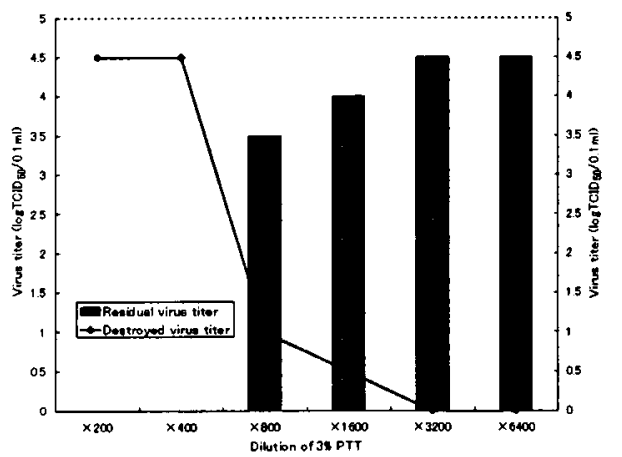

Fig. 2. The effects of iodine disinfectant against several exotic disease viruses. Lines show the titers of the inactivated virus. Bars show the remaining virus titers. The names of viruses were referred to Fig. 1. PTT is the initial letters of potassium tetraglicine triiodide.

this study. Quaternary ammonium compound is used widely as a disinfectant against pathogens including viruses, but the effects of quaternary ammonium compound against viruses are believed to be none or little [5, 12, 14]. However, inactivation of infectious bursal disease virus and SVDV by quaternary ammonium compound with $0.05 \%$ $\mathrm{NaOH}$ was reported recently $[21,22]$. Therefore, in this study, we confirmed the inactivation of several exotic animal diseases viruses by chlorine, iodine and quaternary ammonium compound. And the probable mechanisms of each disinfectant are revealed morphologically by electron microscopy.

The chlorine disinfectant has a volatile character and it is better to use a high concentration. Therefore, this disinfectant is considered to be not very economically useful as a routine disinfectant. However, this disinfectant gives a dose response, so a low concentration is not always ineffective against the viruses. The iodine disinfectant is susceptible to sunshine and it has no dose response; therefore, it is better to use this disinfectant at higher 

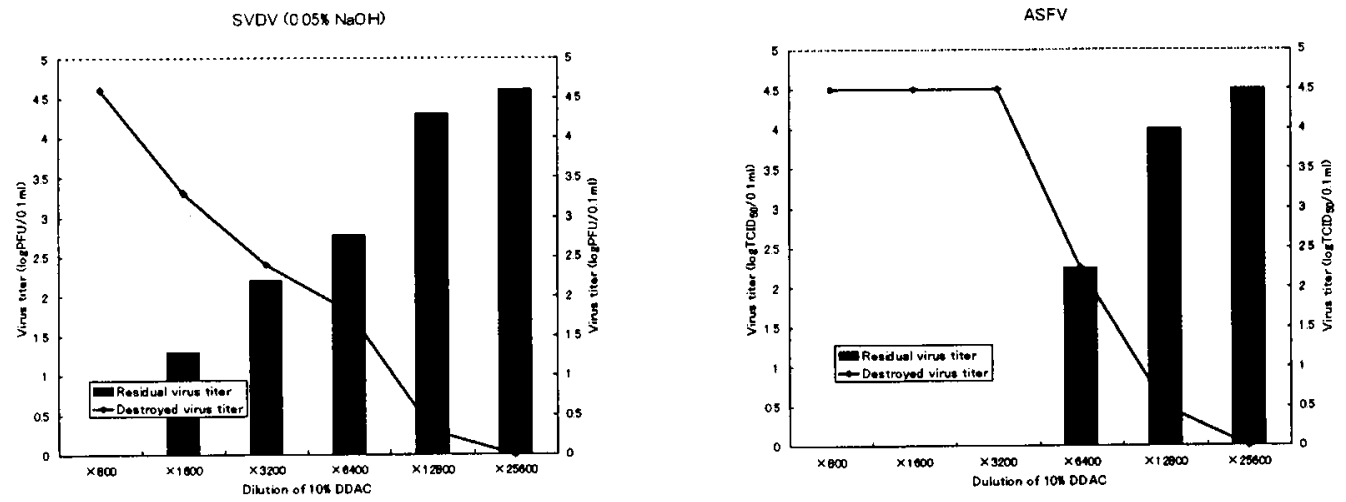

vsv
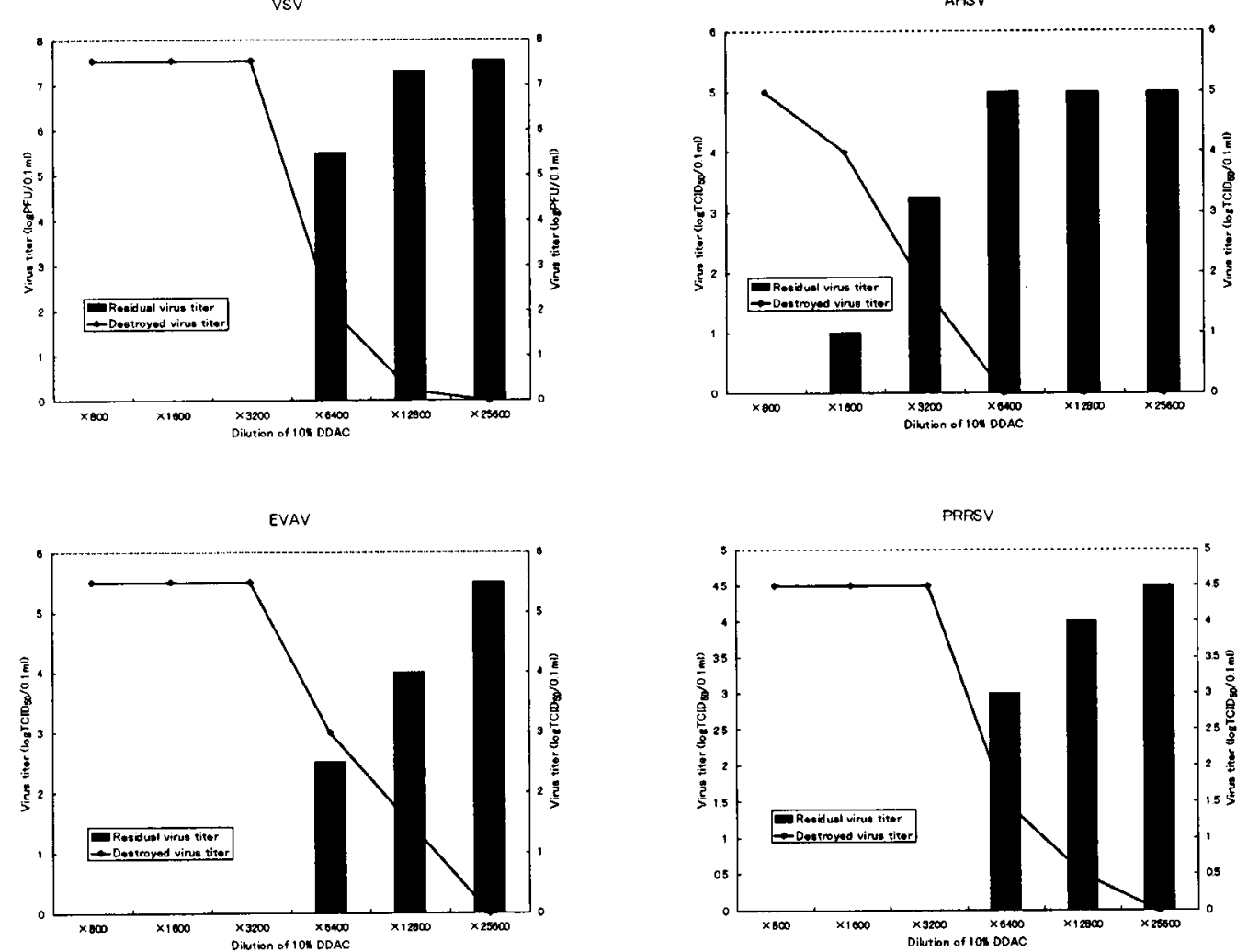

Fig. 3. The effects of quaternary ammonium compound against several exotic disease viruses. Lines show the titers of the inactivated virus. Bars show the remaining virus titers. The names of viruses were referred to Fig.1. DDAC is the initial letters of didecyldimethylammonium chloride.

concentration than chlorine. Non-enveloped viruses such as SVDV and AHSV were considered to be resistant to quaternary ammonium compound $[12,14]$. However, our results showed that AHSV was inactivated at a final concentration of $0.0125 \%$ DDAC.

The mechanism of the effect of chlorine was considered to be degeneration of the virus particles, because the morphological study by electron microscopy revealed a dramatic morphological change and loss of the inner structure of the virus particles. These results were consistent with a previous observation on the efficacy of the action of SHC on bacteriophages [13]. The mechanism of the effect of the iodine was considered to be degeneration of the inner component (nucleoprotein) of the virus particles. The electron micrographs revealed degeneration of inner structure of the virus particles after exposure to iodine disinfectant. This kind of conformational change to the protein by iodine was observed in the case of bacteriophages [3]. The mechanism of the effect of quaternary ammonium compound was considered to be removal of the envelope of 
Table 1. The effects of time for disinfection

\begin{tabular}{|c|c|c|c|c|c|}
\hline \multirow[b]{2}{*}{$\begin{array}{l}\text { Exposure time (minutes) } \\
\text { Viruses and disinfectans* }\end{array}$} & \multicolumn{5}{|c|}{ Percentage of virus inactivated after each exposure time } \\
\hline & 1 & 5 & 10 & 30 & 60 \\
\hline \multicolumn{6}{|c|}{ Swine vesicular disease virus } \\
\hline Chlorine $(0.06 \%)$ & 42 & 50 & 66 & 100 & 100 \\
\hline Iodine $(0.015)$ & 82 & 100 & 100 & 100 & 100 \\
\hline $\begin{array}{l}\text { Quaternary ammonium } \\
\text { compound }(0.0125 \%) \\
\text { with } 0.05 \% \mathrm{NaOH}\end{array}$ & 59 & 62 & 70 & 79 & 100 \\
\hline \multicolumn{6}{|l|}{ Vesicular stomatitis virus } \\
\hline Chlorine $(0.03 \%)$ & 71 & 79 & 100 & 100 & 100 \\
\hline Iodine $(0.0075 \%)$ & 77 & 100 & 100 & 100 & 100 \\
\hline $\begin{array}{l}\text { Quaternary ammonium } \\
\text { compound }(0.003 \%)\end{array}$ & 64 & 67 & 100 & 100 & 100 \\
\hline \multicolumn{6}{|l|}{ African horse sickness virus } \\
\hline Chlorine $(0.0075 \%)$ & 100 & 100 & 100 & 100 & 100 \\
\hline Iodine $(0.0075 \%)$ & 100 & 100 & 100 & 100 & 100 \\
\hline $\begin{array}{l}\text { Quaternary ammonium } \\
\text { compound }(0.0125 \%)\end{array}$ & 81 & 100 & 100 & 100 & 100 \\
\hline \multicolumn{6}{|l|}{ Equine viral arteritis virus } \\
\hline Chlorine $(0.015 \%)$ & 64 & 100 & 100 & 100 & 100 \\
\hline Iodine $(0.015 \%)$ & 100 & 100 & 100 & 100 & 100 \\
\hline $\begin{array}{l}\text { Quaternary ammonium } \\
\text { compound }(0.003 \%)\end{array}$ & 100 & 100 & 100 & 100 & 100 \\
\hline \multicolumn{6}{|c|}{ Porcine reproductive and respiratory syndrome virus } \\
\hline Chlorine $(0.03 \%)$ & 47 & 84 & 100 & 100 & 100 \\
\hline Iodine $(0.0075 \%)$ & 100 & 100 & 100 & 100 & 100 \\
\hline $\begin{array}{l}\text { Quaternary ammonium } \\
\text { compound }(0.0063 \%)\end{array}$ & 100 & 100 & 100 & 100 & 100 \\
\hline
\end{tabular}

* The percentage in the parenthesis indicated in the final concentration of each disinfectant.

the virus and/or micelle formation of virus particles, since it clearly removed the envelope and partially destroyed the virus particles of enveloped viruses. For non-enveloped viruses, quaternary ammonium compound formed nonstructural substances, so called micelle, with or without $0.05 \% \mathrm{NaOH}$.

From these results we conclude that the effects of each disinfectant against several exotic disease viruses are as follows. In order of effectiveness against viruses, it could be considered that the first was the iodine disinfectant, and the second was the chlorine disinfectant. Although the effective concentrations and persistence of both disinfectants are very important, and the effective term of both disinfectants diluted is considered to be short. Therefore, when we use the chlorine and iodine disinfectants, we have to use very fresh and adequately diluted ones. Quaternary ammonium compound did not have the same effect against non-enveloped viruses as the others, but it had much stronger effect against enveloped viruses than the others. Considering the enhancement of the disinfecting effect against non-enveloped viruses when quaternary ammonium compound was used with $0.05 \% \mathrm{NaOH}[21,22]$, it is a very useful disinfectant to use routinely against viral diseases.

Other effects for disinfection, for example, temperature and $\mathrm{pH}$ etc. were not examined in this study. These factors also very important for virucidal effect of disinfection.
Therefore, the further studies are required to reveal the good disinfecting method.

\section{REFERENCES}

1. Blackwell, J.H., Graves, J.H. and McKercher, P.D. 1975. Chemical inactivation of swine vesicular disease virus. $\mathrm{Br}$. Vet. J. 131: 317-323

2. Böhm, R. 1998. Disinfection and hygiene in the veterinary field and disinfection of animal houses and transport vehicles. Intern. Biodeterioration \& Biodegradation 41: 217-224.

3. Brion, G.M. and Silverstein, J. 1999. Iodine disinfection of a model bacteriophage, MS2, demonstrating apparent rebound. Wat. Res. 33: 169-179.

4. Cotton, W.E. 1927. Vesicular stomatitis. Vet. Med. 22: 169175.

5. Denyer, S.P. and Stewart, G.S.A.B. 1998. Mechanisms of action of disinfectants. Intern. Biodeterioration \& Biodegradation 41: 261-268.

6. Donaldson, A.I. 1997. Foot-and-mouth disease in Taiwan. Vet. Rec. 407.

7. Fotheringham, V.J.C. 1995. Disinfection of livestock production premises. Rev. Sci. Tech. Off. Int. Epiz. 14: 191-205.

8. Fotheringham, V.J.C. 1995. Disinfection of stockyards. Rev. Sci. Tech. Off. Int. Epiz. 14: 293-307.

9. Herniman, K.A.J., Medhurst, M., Wilson, J.N. and Sellers, R.F. 1973. The action of heat, chemicals and disinfectants on swine vesicular disease virus. Vet. Rec. 93: 620-624. 


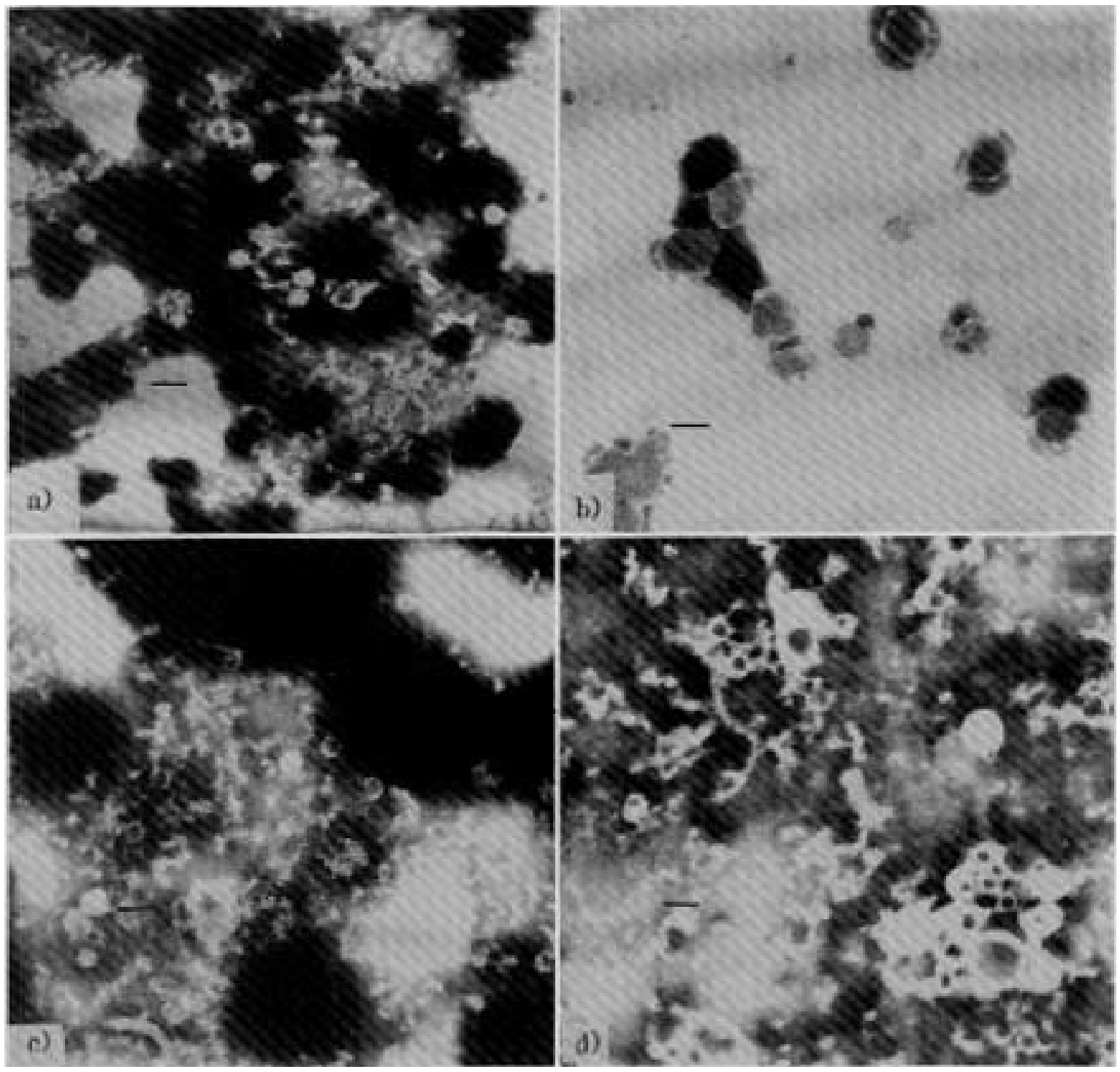

Fig. 4. Electron micrographs of the effects of each disinfectant on African horse sickness virus (AHSV). a) AHSV purified with an equal amount of distilled water, b) AHSV purified with an equal amount of $0.025 \%$ DDAC in quaternary ammonium compound, c) AHSV purified with an equal amount of $0.06 \%$ SHC in chlorine disinfectant, d) AHSV purified with an equal amount of $0.03 \%$ PTT in iodine disinfectant. Bar indicates $100 \mathrm{~nm}$.

10. Jefferey, D.J. 1995. Chemicals used as disinfectants: active ingredients and enhancing additives. Rev. Sci. Tech. Off. Int. Epiz. 14: 57-74.

11. Kanno, T., Inoue, T., Wang, Y., Sarai, A. and Yamaguchi, S. 1995. Identification of the location of antigenic sites of swine vesicular disease virus with neutralization-resistant mutants. J. Gen. Virol. 76: 3099-3106.

12. Kennedy, M.A. 1995. Virucidal efficacy of the newer quaternary ammonium compounds. J. Am. Anim. Hospital Assoc. 31: $254-258$.

13. Maillard, J.Y., Hann, A.C., Baubet, V. and Perrin, R. 1998. Efficacy and mechanisms of action of sodium hypochlorite on Pseudomonas aeruginosa PAO1 phage F116. J. Appl. Microbiol. 85: 925-932.
14. Maris, P. 1995. Modes of action of disinfectants. Rev. Sci. Tech. Off. Int. Epiz., 14: 47-55.

15. McCollum W.H. 1969. Development of a modified virus strain and vaccine for equine viral arteritis. J. Am. Vet. Med. Assoc. 115: 318-322.

16. Mizukoshi, N., Sakamoto, K., Iwata, A., Tsuchiya, T., Ueda, S., Watanabe, T., Kamada, M. and Fukusho, A. 1992. The complete sequence of African horsesickness virus serotype 4 (vaccine strain) RNA segment 5 and its predicted polypeptide compared with NS1 of bluetongue virus. J. Gen. Virol. 73: 2425-2428.

17. Murakami, Y., Kato, A., Tsuda, T., Morozumi, T., Miura, Y. and Sugimura, T. 1994. Isolation and serological characterization of porcine reproductive and respiratory syndrome 


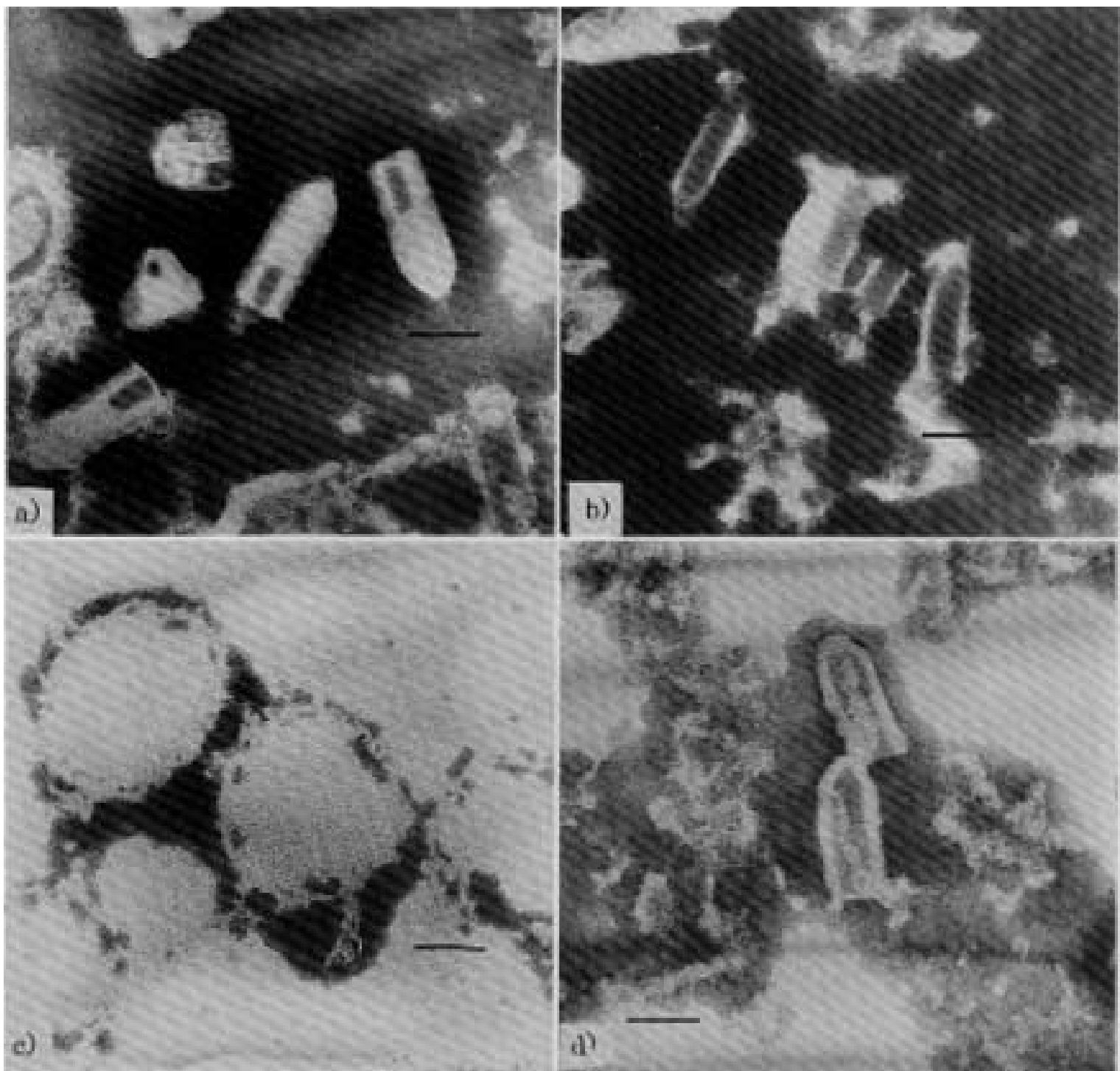

Fig. 5. Electron micrographs of the effects of each disinfectant on vesicular stomatitis virus (VSV). a) VSV purified with an equal amount of distilled water, b) VSV purified with an equal amount of $0.025 \%$ DDAC in quaternary ammonium compound, c) VSV purified with an equal amount of $0.06 \%$ SHC in chlorine disinfectant, d) VSV purified with an equal amount of $0.03 \%$ PTT in iodine disinfectant. Bar indicates $100 \mathrm{~nm}$.

(PRRS) viruses from pigs with reproductive and respiratory disorders in Japan. J. Vet. Med. Sci. 56: 891-894.

18. Owen, J.M. 1995. Disinfection of farrowing pens. Rev. Sci. Tech. Off. Int. Epiz. 14: 381-391.

19. Rees, W.H.G., OIE Code Commission. 1992. List A diseases. pp 57-165. OIE International Animal Health Code 6th ed.

20. Sanchez Botija, C. 1963. Modification del virus de la peste porcina africana en cultivos celulares. Contribucion al conocimiento de la accion patogena y del poder de proteccion de las estirpes atenuadas. Bull. Off. Int. Epizoot. 60: 901-919.

21. Shirai, J., Kanno, T., Inoue, T., Mitsubayashi, S. and Seki, R.
1997. Effects of quaternary ammonium compounds with $0.1 \%$ sodium hydroxide on swine vesicular disease virus. J. Vet. Med. Sci. 59: 323-328.

22. Shirai, J., Seki, R., Kamimura, R. and Mitsubayashi, S. 1994 Effects of invert soap with $0.05 \%$ sodium hydroxide on infectious bursal disease virus. Avian Dis. 38: 240-243.

23. Tokuda, G., Tokui, T., Khono, M., Nakagawa, T., Kumagai, T. and Sasahara, J. 1975. Experimental infection of pigs with swine vesicular disease virus isolated in Japan. Bull. Natl Inst. Anim. Health 70: 19-26 (in Japanese with English summary). 